\title{
Factor analysis of energy saving in households
}

\author{
Rais Burganov $v^{1, *}$, Emina Altynbaeva ${ }^{2}$ and Ludmila Maimakova ${ }^{3}$ \\ ${ }^{1}$ Kazan State Power Engineering University, Russia \\ ${ }^{2}$ Kazan State Power Engineering University, Russia \\ ${ }^{3}$ Kazan State Power Engineering University, Russia
}

\begin{abstract}
The paper discusses such issues as the role and importance of studying energy-saving behavior of households in the national economy and society, the need for new methodological approaches to their study, neoclassical, institutional, technological approaches to the study of the behavior of households in the energy sector. Also the basics of construction of multi-parameter mathematical models of household behavior are proposed..
\end{abstract}

\section{Introduction}

The energy-saving behavior of households as an object of research is constantly in the field of view of researchers from different countries. Among the significant works in recent years, one can single out the study by Mahmoud Salari and Roxana J. Javid on modeling household energy expenditures in the United States [1], Boudet X. and others on clustering energysaving behavior in the family [2], Ito and Koichiro on the consumption or the average price of electricity [3]. Much attention in scientific works is paid to the study of individual manifestations of the energy-saving process, such as the problem of managing energy conservation in an apartment building, in everyday life. However, in order to solve the problems facing mankind in the field of ensuring the demand of economic entities and society for energy consumption, deeper and more fundamental research is needed, based on the principles of economic theory. It is not just about energy energy, but other types as well [4].

\section{Data and Methods}

The solution of problems in the field of energy saving of the population is one of the most important tasks of the state economic policy of any country, since the population of the Russian Federation consumes more than $14 \%$ of the total amount of electricity. According to statistics, in the structure of consumer spending by households in the Russian Federation, electricity consumption in 2018 amounted to 1.4 percent of the final data. A separate issue is the efficiency of energy use by all types of households. So, according to the researcher Boogen Nina in Switzerland, the average inefficiency of electricity use by Swiss households is about 20-25\% [5]. Probably, in Russia, the population

\footnotetext{
* Corresponding author: burraabr@gmail.com
}

spends inefficiently a large share of total energy, including electricity.

The solution of problems in the field of energy saving of the population is one of the most important tasks of the state economic policy of any country, since the population of the Russian Federation consumes more than $14 \%$ of the total amount of electricity. According to statistics, in the structure of consumer spending by households in the Russian Federation, electricity consumption in 2018 amounted to 1.4 percent of the final data. A separate issue is the efficiency of energy use by all types of households. So, according to the researcher Boogen Nina in Switzerland, the average inefficiency of electricity use by Swiss households is about $20-25 \%$ [5]. Probably, in Russia, the population spends inefficiently a large share of total energy, including electricity.

\section{Results}

A deep study of the energy-saving behavior of households as an object of research and projects should be based on theoretical and methodological approaches, which determine the effectiveness of the measures taken in the field of energy conservation. Depending on these methods, the mechanism for achieving the final goal, namely the optimization of energy consumption at different levels of management, can be predetermined. Thus, the energy-saving behavior of households as an object of study of integral science will receive a more fundamental justification if the methodology of economic theory is used.

Thus, from the point of view of representatives of the neoclassical direction of economic theory, the behavior of households in the use of energy resources is characterized by such concepts as "utility", "benefit", "profitability", "marginal", etc. Energy elasticity is essential for shaping household behavior. It is known that the most stimulating direction in energy saving is 
getting benefits from energy saving, that is, there is a market model of consumer behavior. The increase in electricity debt is one of the most pressing problems. Turning off the lights on time, good housekeeping and the use of energy-saving lamps in the household can save a lot of energy.

Resh Energy-saving behavior of households in terms of institutional theory is defined by such concepts as "institutions", "rules and regulations", "property", "energy contracts", etc. The institutional behavior of households in the energy sector is also influenced by informal norms. Among the problems is the theft of electricity. If in European countries the volume of theft does not exceed $4 \%$, in the USA - $1-2 \%$, then in many regions of our country it reaches $18-30 \%$ of the total electricity consumption. According to experts, half of this figure is the so-called technical losses, the other half is unaccounted electricity consumption, in other words, theft. From the side of the institutional theory, it is also possible to study the influence of the institution of ownership on the energy saving of households. In particular, the principles of using electricity by households in their apartment are different from using electricity in a common space. The lack of incentives for apartment owners to carry out energy saving measures and equipping buildings with general house metering devices makes itself felt. Laws, bylaws and other governing rules of the game in the energy sector are constantly reviewed, supplemented, etc. This is especially noticeable in the field of providing energy services to the population. Each year, households face changes in electricity tariffs, billing, etc.

According to the moral and educational concept as a part of institutionalism, the energy consumption of households is related to such institutions as customs and traditions, a careful attitude to energy - heat resources. Thus, researchers Marlyne Sahakian and Béatrice Bertho have identified the effect of household emotions on both reducing and improving energy use [6].

The technological concept of energy-saving behavior of households involves the use of modern energy-saving technologies. "Smart home", "smart city", "smart grids" are already becoming common concepts. Energy efficient technologies hold great promise for reducing the financial costs of households. For example, it is no longer a secret for anyone that LED lamps are more profitable than incandescent lamps of the old type. Technologies do not stand still, therefore there are a huge number of devices and systems for energy saving and energy efficiency. In particular, researchers from the University of Gothenburg have found a way to turn ordinary windows into solar-powered heaters that can significantly increase the temperature of the glass, even in freezing weather. The main functional components of the invention are plasmonic nanoantennas. With the help of plasmons, nanoantennas are capable of intensely absorbing light, which then heats up the entire surface.

In the economic-mathematical model, the process of energy-saving behavior of households can be described by a single or multi-parameter representations.

In a model with one parameter, it is possible to take the growth (or vice versa) of the population's income, which most of all forms the energy-saving behavior of energy users.

The multiparameter mathematical models take into account the influence of external (main and secondary) and internal (main and auxiliary) factors on the energysaving behavior of households. Each variable can be positively or negatively reflected in the rational or irrational in the behavior of households in energy saving.

So, external factors, that is, influencing the process of energy saving from outside, include:

- the main factor (determining the purpose and meaning of energy saving), for example, a change in energy prices or the introduction of a tax on income received as a result of energy savings in households;

- minor factors (affecting the actions and interrelationships of the elements of the energy saving system), for example, the use of outdated house infrastructure of power grids, an increase in the number of used gadgets.

Internal factors of energy saving in households, that is, influencing the process of energy saving from within the energy saving system, include:

- basic (target settings in energy saving of family members), as using the principle "when leaving, turn off the light";

- auxiliary (for example, the level of equipment with energy-saving devices, the presence of energy receivers in the household with the class "A +++".

\section{Discusion and Conclusion}

The factorial approach will allow finding more viable models for the development of energy conservation in households.

At the same time, it is necessary to pay attention to the need for government intervention in the process of shaping energy-saving behavior of households. The state should take certain measures to form the optimal energysaving behavior of households, taking into account their possibilities of using nature-like technologies. For example, in France, the cost of purchasing energy efficient equipment is deducted from the tax base of citizens.

In general, the current state of development of energy-saving and nature-like technologies will transform the behavior of households in the field of consumption of any type of energy.

\section{Acknowledgments. The reported study was funded by RFBR, project number 20-01-00001-00099 "Theoretical and methodological approaches to the development of models of energy-saving behavior of households in a nature-like} economy.

\section{References}

1. S.Mahmoud, J.Roxana et el. Modeling household energy expenditure in the United States. Renewable and Sustainable Energy Reviews. Vol. 69, , Pages 822-832. (2017) 
2. Boudet et al. Clustering household energysaving behaviors by behavioral attribute. Energy Policy. Vol. 92: pp. 444-454. (2016)

3. Ito, Koichiro.Do Consumers Respond to Marginal or Average Price? Evidence from Nonlinear Electricity Pricing. American Economic Review. Vol. 104 (2): 537-63. (2014)

$4 . \quad$ R.A.Burganov, L.Maimakova, L.Urazbakhtina and L.Golitsyna. On the need to improve the methodology for calculating energy saving and energy efficiency of enterprises. IOP Conference Series: Materials Science and Engineering, Volume 791, IV International Scientific and Technical Conference "Energy Systems" 31 October - 1 November 2019, Belgorod, Russia. https:// DOI: 10.1088/1757$\underline{899 X / 791 / 1 / 012040}$ (2019)

5. N.Boogen. Estimating the potential for electricity savings in households. Energy Economics. 2 Vol. 63. pp. 288-300. (2017)

6 S.Marlyne, Béatrice Bertho. Exploring emotions and norms around Swiss household energy usage: When methods inform understandings of the social, Energy Research \& Social Science, Vol. 45., P. 81-90, https://doi.org/10.1016/j.erss.2018.06.017( 2018) 